\title{
Pirates and merchants - Hanse traders and Victual Brothers in Skjernesund and other outports of southernmost Norway in the early fifteenth century
}

\author{
FRANS-ARNE H. STYLEGAR, PÅL NYMOEN AND GUNNAR EIKLI
}

\begin{abstract}
Stylegar, F.-A. H., Nymoen, P., Eikli, G. 2019. Pirates and merchants - Hanse traders and Victual Brothers in Skjernesund and other outports of southernmost Norway in the early fifteenth century. AmS-Skrifter 27, 245-257, Stavanger, ISSN 0800-0816, ISBN 978-82-7760-183-0.

Friend or foe? Trader or pirate? Commercial shipping along the archipelago of southern Norway in the early fifteenth century could be a risky business. Hanseatic skippers must have had detailed knowledge of sailing routes and good harbours along the route past Lindesnes towards Bergen. Among a chain of good natural harbours, Skjernesund near Mandal formed a hub, a protected inner route consisting of several good harbour areas sheltered from the exposed Skagerrak north of Skjernøya. An overview of dated shipwrecks along the coast of southern Norway is presented and their context discussed in relation to why they wrecked. It is striking that the majority of wrecks have been found in port areas. The most common interpretation of these wrecks individually is that there are natural explanations for these as losses at sea. By comparing the written sources and historical events from the main period of these shipwrecks, it is probable that in many cases the cause was piracy.
\end{abstract}

Frans-Arne H. Stylegar, Multiconsult Norge, Rigedalen 15, N-4626 KRISTIANSAND, NORWAY

E-mail: fas@multiconsult.no

Pål Nymoen, Norwegian Maritime Museum, Bygdøynesveien 37, N-0286 OSLO, NORWAY

E-mail: pal.nymoen@marmuseum.no

Gunnar Eikli, Sumatraveien 21A, N-4623 KRISTIANSAND, NORWAY

Keywords: Victual Brothers, Hanse merchants, outports, shipwrecks, piracy

There used to hang in Marienkirche (St Mary's Church) in Lübeck, over the chair belonging to the Bergenfahrer, a banner that was captured in 1526 from pirates in Skjernesund, a natural harbour on the southernmost coast of Norway. Two Hanse ships, with skippers Karsten Tode 'the Old' from Lübeck and Claus Went from Wismar, sailing from Bergen and seeking harbour in Skjernesund, became aware of a crayer in a bay nearby. According to a contemporary account by Gert Korfmaker, the Germans feared that it was a pirate ship, because one of them said that this was a well-known pirates' nest. But others said: 'May God have mercy on us, that it is rather a Scotsman loading timber'. ${ }^{1}$ But pirates they were, and after some struggle the Hansards managed to overcome the pirate ship, whose captain was Marten Pechlin from the island of Fehmarn in the west Baltic; Pechlin himself was killed during the battle, and the surviving pirates were thrown into the sea. ${ }^{2}$
In certain respects, seafarers had been asking the same question from time immemorial when meeting other, unknown ships: Friend or foe? Trader or pirate? For the Hansards, this was of course a question of great importance when, during their heyday, the trade in fish centred on Bergen in western Norway was of considerable worth to the Hanse. In the traffic between Bergen and the Baltic Region, Skjernesund seems to have been something of a hub, and an important harbour for the Hanse, as well as for pirates. The present paper discusses the place of the south Norwegian coast in Hanseatic seafaring from the late fourteenth to the late fifteenth century, a problematic time for seafaring due to war between seafaring nations and widespread piracy. Particular emphasis is given to Skjernesund.

All ships sailing between the North Sea and the Baltic had to pass the coast of Agder in the southernmost part of Norway. The state of navigational knowledge in the late medieval period, together with the sailing abilities 
of the ships, physical conditions in the form of prevailing winds and currents, and geographical-topographical conditions meant that one had to steer clear of the western coast of Denmark, which had very few good harbours. The oldest preserved Seebuch from c. 1470 accordingly sets Cape Lindesnes as the main point for sighting land for ships coming from the North Sea and sailing into the Baltic. ${ }^{3}$ The Agder coast has the largest number of registered shipwrecks in Norway, and also most of those dating to the medieval period. ${ }^{4}$ The Norwegian topographical writer and clergyman, Peder Claussøn Friis, who lived in the Lindesnes area in the latter half of the sixteenth century, made the same argument: 'This Naze is well-known by all Seafaring People in this Western Ocean, because from here they have their Land-Sighting, and from here they set their Course to other Countries'. ${ }^{5}$ But he also appreciated that there was a downside to the area's many good harbours and general importance for seaborne traffic: 'No other place in Norway has been as tormented by pirates and freebooters as this, both because of its availability and the good harbours here.... ${ }^{6}$

\section{Maritime archaeology in Skjernesund}

Skjernesund belongs to the chain of outports (Norw. uthavner) along the Skagerrak coast of southern Norway. ${ }^{7}$ It is situated on an island, Skjernøy, separated from the mainland only by a narrow sound, near the town of Mandal. In the eighteenth and nineteenth centuries, Skjernesund, along with the other outports, was a thriving community specializing in servicing sailing ships seeking harbour here. Until recently, it was known first and foremost for its many well-preserved houses dating from this period, including the old inn that has been dated by dendrochronology to 1640 . Only folk memory hinted that Skjernesund might have played a different role in an even earlier period; stories about pirates and sea battles abound on the island and in its vicinity. ${ }^{8}$ Latterly, these stories started to find support in the archaeological material.

Much new material has come to light at the sea bottom in the Skjernesund area in later years, and we have the very active and competent local divers in Mandal and Farsund to thank for that. Several shipwrecks have been located, as well as larger areas rich in artefacts, in a few cases in so great numbers that it seems correct to call these cultural layers. Both the cultural layers and the shipwrecks are situated in typical natural harbours, protected from wind and waves (Fig. 1). There is nothing to suggest that the ships came here by accident; rather, the context, in shallow water inside protected bays, seems to indicate that we are dealing either with discarded vessels which sunk while moored, or were abandoned and then sunk, or were intentionally sunk. So far, three shipwrecks have been located, and there are unsubstantiated reports of a fourth. Two of the wrecks show traces of burning. The Norwegian Maritime Museum has followed up new information as it became available from the local sports divers, in addition to conducting some more sporadic surveying work on its own. One of the shipwrecks has been excavated by the University of Southern Denmark. ${ }^{9}$

Wreck 1 is a relatively large, caravel-built ship, probably built in the Netherlands around $1620 .{ }^{10}$ It lies in shallow water close to the beach in an inlet near the Skjernesund passage. Several artefacts are visible at the sea bottom, both overlaying and surrounding the wreck, but there is little to suggest that this is cargo or inventory from the vessel; it is more likely part of a more extensive cultural layer accumulated through the use of this particular inlet for mooring, loading and unloading for a substantial period.

Wreck 2 is a clinker-built vessel now covered by balast material. The divers who uncovered parts of the hull made observations to the effect that the ship had been burnt. Wreck 2 is not closely dated, but typological aspects of the ship's hull and nails indicate that it is of late medieval date. ${ }^{11}$ Like Wreck 1 , Wreck 2 lies close to land, in an inlet near Skjernesund.

A third ship, Wreck 3, has been excavated. Here, we are dealing with the bottom section of a clinkerbuilt vessel with a cargo of barrels of lime and other goods. The wreck lies in a natural harbour, but at some distance from land. The excavation and subsequent dendrochronological study shows that Wreck 3 is the remains of a c. $26 \mathrm{~m}$ long freight vessel built in 1389 with timber from Poland.

These shipwrecks, their chronology and their context suggest that Skjernesund has a long history as a harbour. There are also clear indications that the sea bed in the area contains archaeological material in the form of cultural layers built up through waste refuse from ships and from land, as well as from objects lost into the water where ships have been anchored and where they have been loaded and unloaded. The cultural layers have not been excavated, and it is impossible at this junction to determine the size of these layers. However, divers' reports and some surface surveying suggest that artefacts can be expected over substantial areas. Two harbour sites or anchorages seem to have particularly 

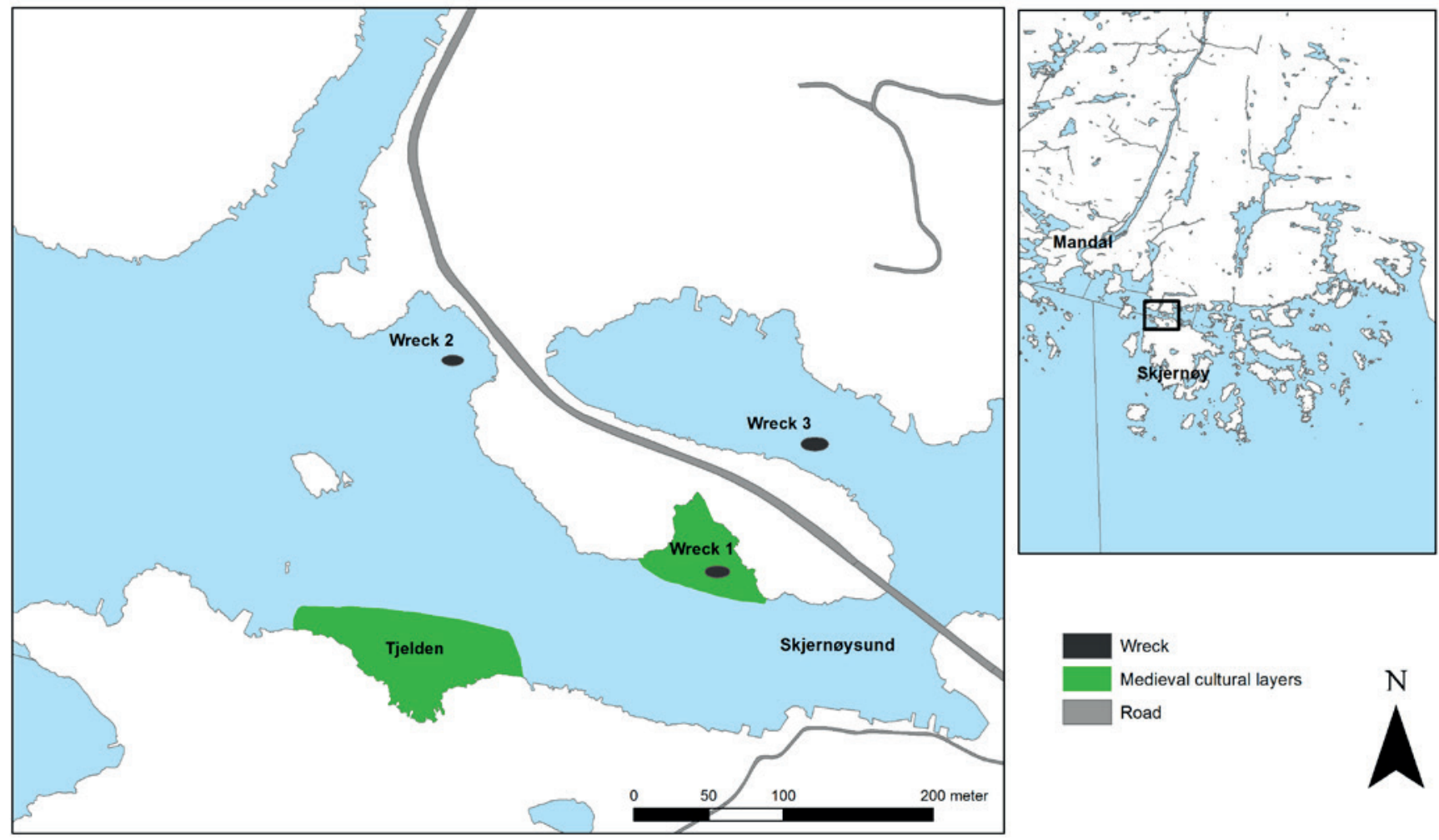

Fig. 1. Map showing location of the wrecks 1-3 at Skjernesund and extent of port areas with medieval culture layers (illustration: Morten Reitan and Pål Nymoen, Norwegian Maritime Museum).

Fig. 2. Examples of Siegburg-type ceramics spread around the sea bed at Tjelden (photo: Pål Nymoen, Norwegian Maritime Museum).
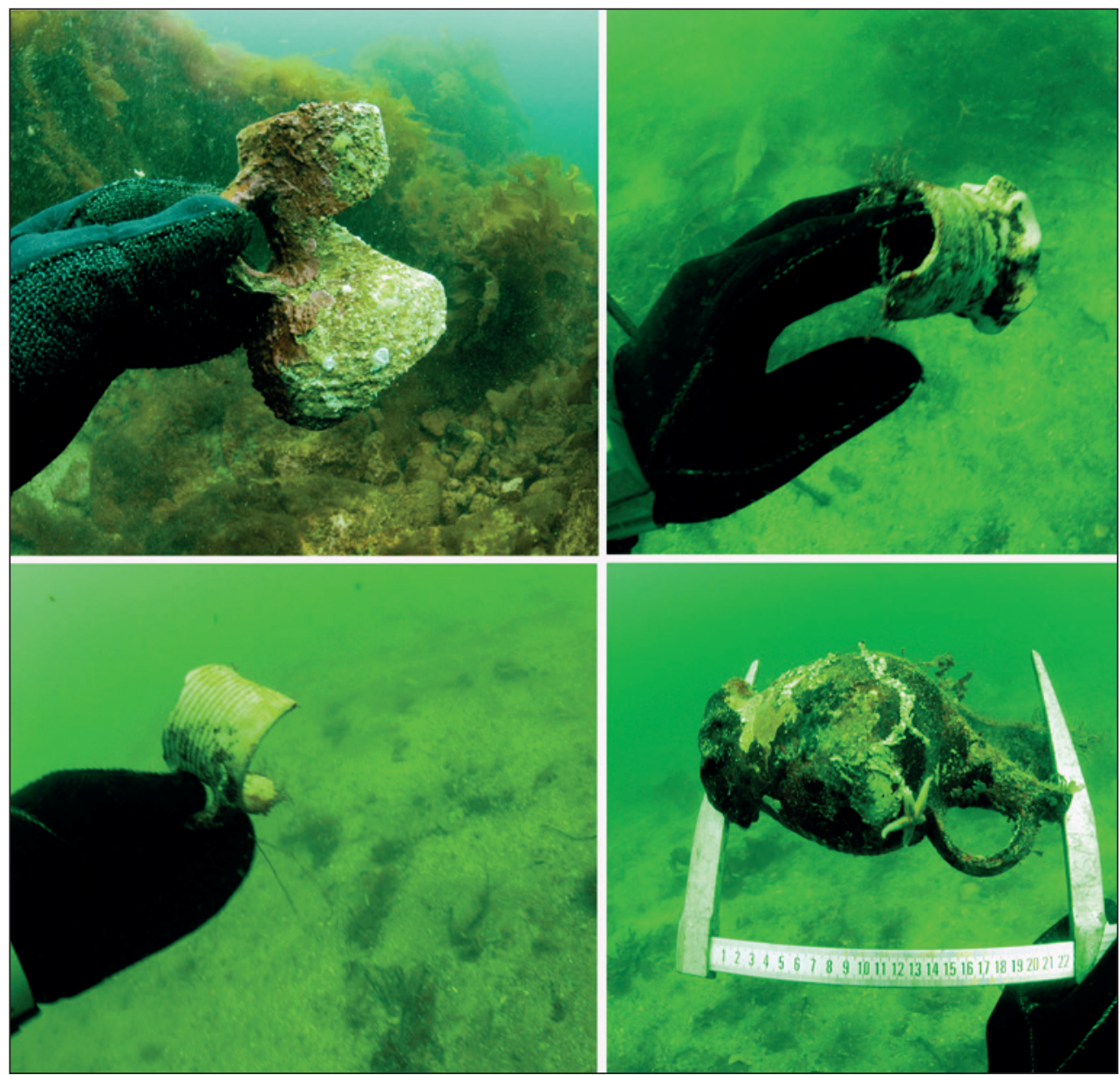
thick cultural layers, which also include much material of late medieval date. One of these cultural layers seems to be concentrated in the same inlet which also includes Wreck 1. Here, ballast and ceramic material are partly contained in the sediment, and partly visible on the sea bed (Fig. 2). Some of the pottery is late medieval, among them jugs and drinking vessels of Siegburg stoneware. There is also a pewter vessel of a type often associated with the Hanse. ${ }^{12}$

Another area with substantial cultural layers has been surveyed at Tjelden, near the western entrance to the sound and just outside of the historical outport settlement. Archaeologists became aware of this site when sport divers reported observations of hones and a quern stone lying on the sea bed, and, later, stone cannon balls and coarse timbers, probably from a shipwreck (the above-mentioned fourth wreck). When the museum conducted a survey, it became clear that also huge concentrations of ballast, waste from animalslaughter and pottery were to be found there (Fig. 3). ${ }^{13}$ Typologically, the pottery belongs to the period between the thirteenth and seventeenth centuries. The Siegburg pottery from the cultural layers at Tjelden consists of a number of complete and almost complete vessels, as well as several sherds. 'Hanse' pottery dominated, and this, in combination with absence of modern pottery and clay pipes, gives a clear impression that this particular area has not been used extensively since the late medieval period. It is furthermore noteworthy that there is lots of refuse from butchery in the sediments here. The topography at Tjelden means that even quite large ships can lie near land. From the looks of it, this used to be the practice, since many artefacts lie on the sea bed very close to land. The only other Norwegian site we know of with similar finds is the harbour at Avaldsnes, where there are clear indications that the Hansards had a presence in the fourteenth and fifteenth centuries (see the chapters by Elvestad and Opedal, Ersland, and Fyllingsnes, this volume). ${ }^{14}$

How are we to interpret the sites at Skjernesund, and the cultural layers at Tjelden in particular? It is difficult, at least based on purely archaeological sources, to establish whether the layers result from ships that only stayed overnight or from trading activity. However, there are some clear signs that reloading took place. First, there seems to be too much debris from slaughter if the idea is that these are the remains of meals eaten while onboard. The sheer volume might indicate that we are dealing with the on-site butchery of animals acquired from local people and taken onboard, either as provisions or for salting and resale. Second, there is

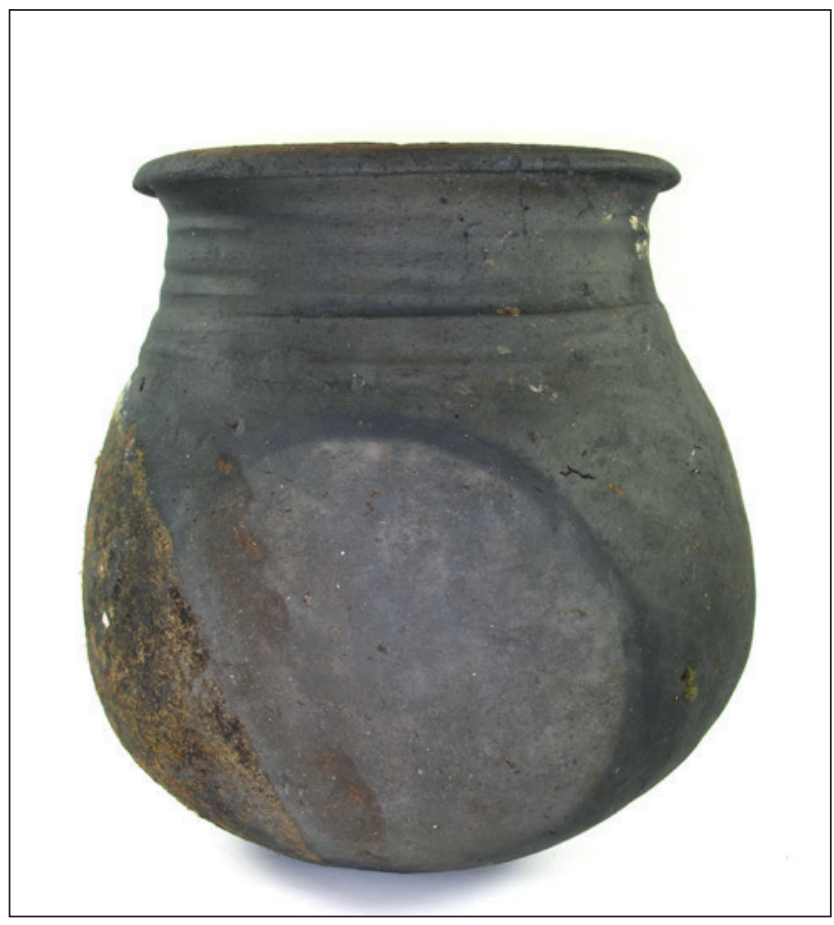

Fig. 3. Ceramic pot found in the culture layers at Tjelden. Height $27 \mathrm{~cm}$, largest diameter $26 \mathrm{~cm}$, outer diameter $18.4 \times 20.2 \mathrm{~cm}$. According to Wahlöö $(1976,304)$ it can be typologically dated back to the 1200-1300 century (photo: Pål Nymoen, Norwegian Maritime Museum).

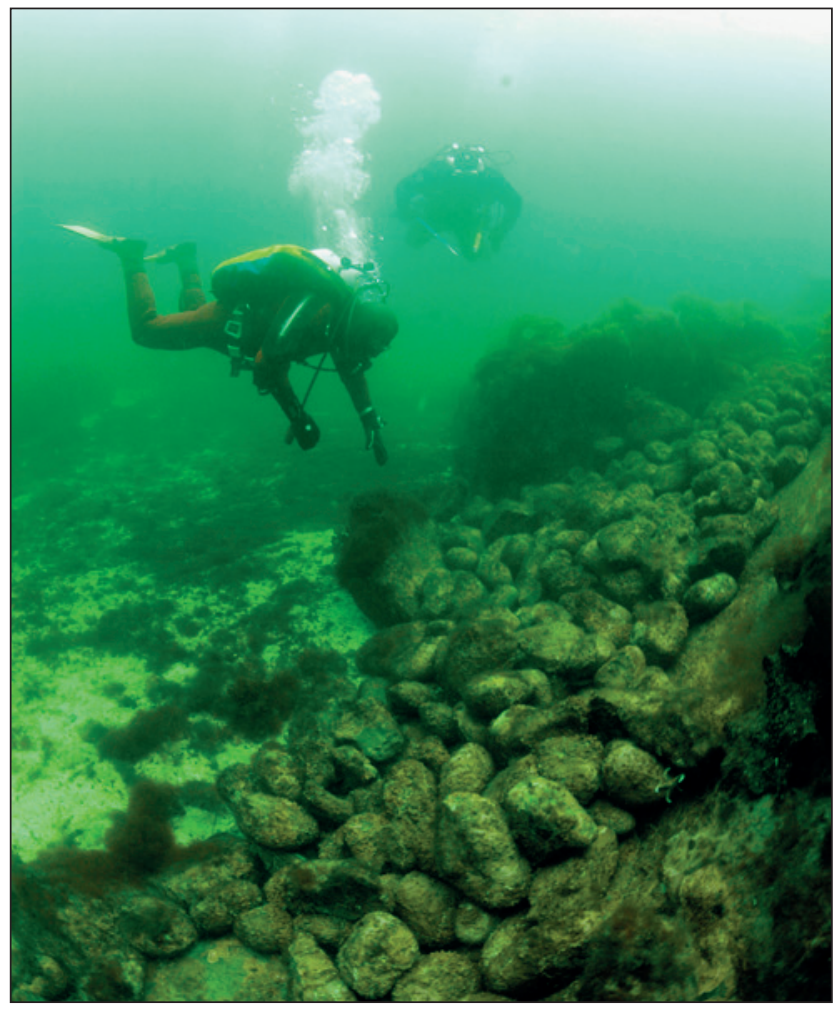

Fig. 4. Flint ballast on the sea bed close to Tjelden, Skjernesund (photo: Pål Nymoen, Norwegian Maritime Museum). 
considerable ballast in the form of non-local stones on the sea bed at Tjelden - flint nodules amongst them (Fig. 4). This, of course, indicates that some kind of cargo has replaced the ballast, perhaps timber or barrels of salted meat.

More excavation and survey work are necessary to understand the context of these finds. But a working hypothesis is that the cultural layers result from ships being anchored in the area, and the volume of Siegburg stoneware suggests that Hanseatic merchants may have been among those who used the site. Pottery from Siegburg usually dates from $c .1300-c .1600 .{ }^{15}$ Siegburg ware is found in harbour contexts in many places, often places frequented by Hanseatic merchants, and in many cases in towns where the Hanse traded. ${ }^{16}$ Gaimster's view, which is based on his analysis of work done in the Baltic, is that this ware was not brought as cargo, but was used by the merchants themselves for serving and drinking wine. It remains to be determined whether this holds true also for Agder and other coastal areas in Norway. The volume of Siegburg ware produced must have been massive, and it has been suggested that Siegburg ware could have been a major marker of identity and fellowship within the Hanse (Fig. 5). ${ }^{17}$

\section{Process or event? Lessons of 1526}

We should not forget the concerns of the Hanseatic skippers in 1526, who were not sure whether the ship they discovered near Skjernesund was a pirate or a peaceful merchant vessel loading timber. In their case, their worst fears came true. We know from other sources that Skjernesund at that time was a pirates' nest, at least as seen from the Hanse's perspective. In the very same year (1526), a report by Hans Michelssøn to King Christian II, formerly of Denmark but at that time exiled in Brabant, states that one of his privateers, skipper Clement, lay with five ships in Skjernesund, two miles $(22 \mathrm{~km})$ northeast of Nesset (Lindesnes) 'where he has erected two blockhouses at each side of the bay and closed the harbour with iron chains', and that all bosmend and hoffmend (sailors and men of war) in Norway are coming to him. ${ }^{18}$ Marten Pechlin, too, was in the service of King Christian, and a sworn enemy of the Hanse. In just a few days, he is reported to have taken twelve Hanse ships which were en route to Sweden, and thrown 105 sailors over board. In 1526, as part of King Christian's campaign against his former kingdom and its Hanse allies, he plundered several churches and monasteries on the Norwegian coast. He pursued the then-common strategy of demanding a

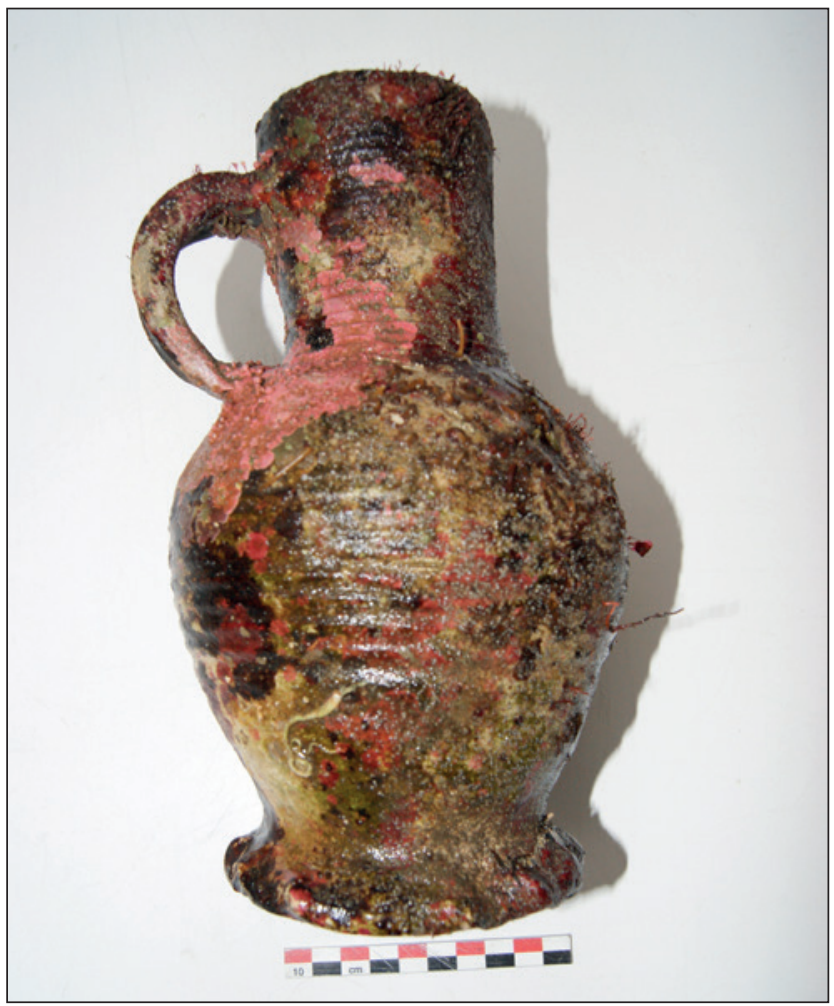

Fig. 5. Siegburg stoneware jug found in March 2012 among ballast, waste and amounts of breakage from similar and other pottery objects in the culture layers at Tjelden, Skjernesund. Height $23 \mathrm{~cm}$, largest diameter $14 \mathrm{~cm}$, diameter bottom approx. $11 \mathrm{~cm}$ (photo: Pål Nymoen, Norwegian Maritime Museum).

huge ransom for the ships he captured, and if the owners did not comply, Pechlin 'sunk' the ships. The victorious Hansards showed no mercy with the infamous privateer and his crew; of the eighty-man strong crew, only nineteen survived the battle near Skjernesund. Six were taken prisoner, summarily sentenced and thrown overboard. Another thirteen escaped in two boats; four of these were picked up by a ship from Rostock and drowned. The others were later beheaded in Varberg in present-day Sweden by the only surviving crew member, who was freed for this purpose. ${ }^{19}$

What Gert Korfmaker and his companions discovered in 1526, was that a much-visited harbour had become infested with pirates. Here then, we have another scenario that may explain archaeological contexts like the one we meet in Skjernesund - piracy, that is, and not trade - or rather both, since the first makes little sense without the second. The intentional sinking of captured vessels may actually be what lies behind wrecks like the ones in Skjernesund, burnt or not.

It seems to us that maritime archaeologists too often have looked to natural, processual causes when trying to interpret their find material, rather than searching 


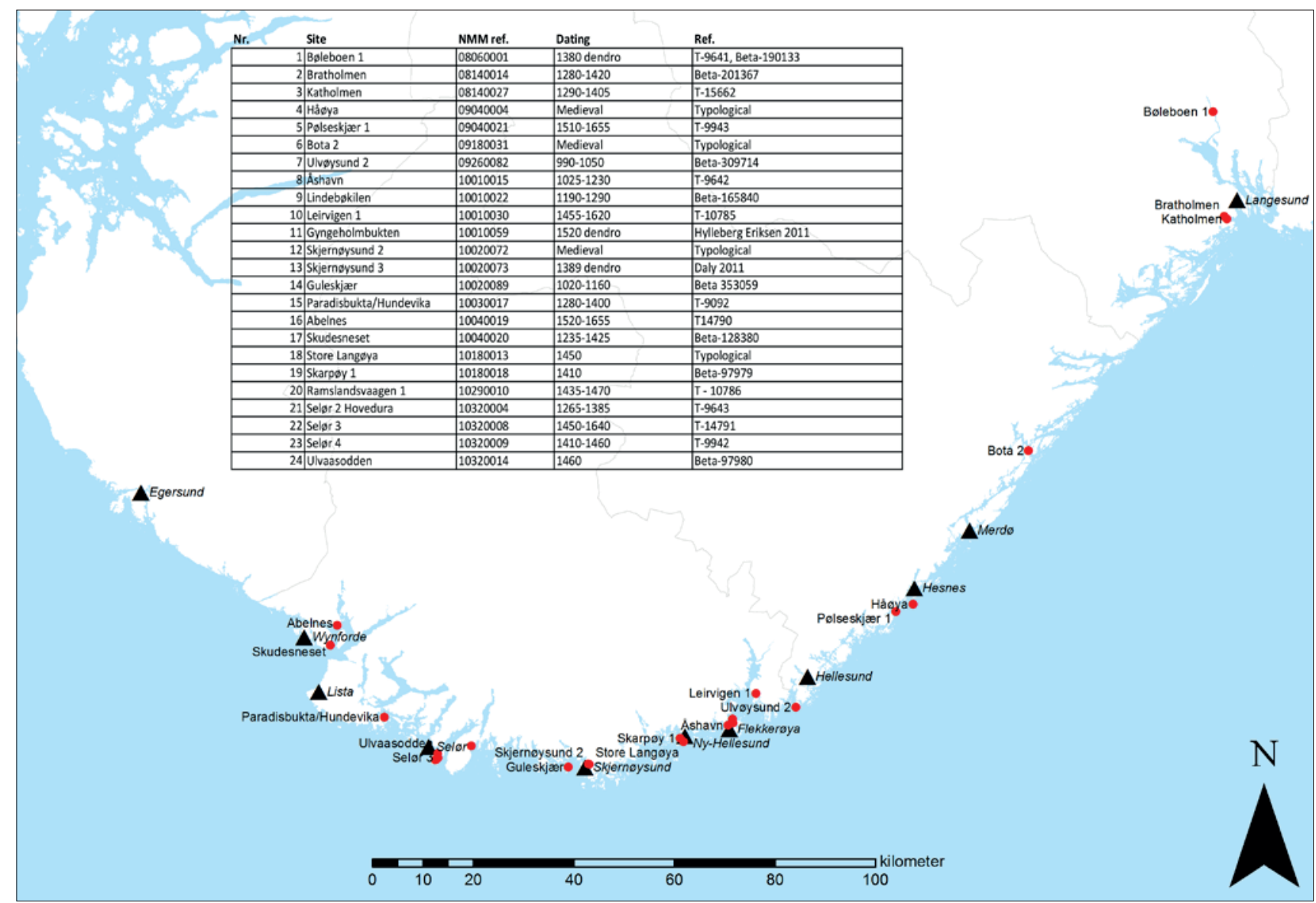

Fig. 6. Ports (triangle) mentioned in the text, location of wreck (circle) and table with dates (illustration: Pål Nymoen and Morten Reitan, Norwegian Maritime Museum).

for specific historical events, even in cases where exact dates and place of origin are available through dendrochronology and the find context itself suggests otherwise. The late medieval wreck from Hundevika near Farsund (Fig. 6, no. 15), for instance, which is situated in a sheltered bay in shallow water and with traces of burning on its timbers, was interpreted as a vessel that 'may have sprung leak and had been beached', while the traces of burning 'may indicate fire on board, if not secondary after the ship had been emptied of valuable items by the crew or local looters. Another possibility, would be simple fire-marks from bending the wood over an open fire.' ${ }^{20}$

Gert Korfmaker's story furnishes us with several other possibilities: First, our Hanse skippers noticed a large hulk, a certain ship type, in an inlet near Skjernesund. It had been seized by the pirates, demasted and left in shallow water; at high tide, she was filled with water. ${ }^{21}$ The ship's crew stayed at a nearby farm, while its captain had gone home to Tønsberg to try and raise the ransom money demanded by Pechlin and his compatriots to release the vessel..$^{22}$ Then, during the ensuing battle the pirates tried to steer a fire ship into the Hanse fleet. ${ }^{23}$
And, after their victory, the German merchants took everything of value, anchors, ropes and sails as well as cargo, and set the conquered pirates' ship on fire. ${ }^{24}$ Each of these scenarios could explain wrecks like the one in Hundevika.

\section{Other late-medieval shipwrecks}

An interesting pattern emerges if one surveys the whole corpus of shipwrecks dated to before $c .1600$ on the southern coast of Norway. In total, there are twentyone such wrecks from the coastal areas in the counties of Telemark, Aust-Agder and Vest-Agder that are dated, either by dendrochronology or by radiocarbon. ${ }^{25}$ Both the dates and the find contexts are of considerable interest.

First, almost all the wrecks are situated in harbours and/or in shallow water, while only two or three were found in deeper, more open sea. Four of the former furthermore show traces of burning (as do some other finds which are of late-medieval date, but not more closely dated). As is the case with the Skjernesund wrecks, there is little to suggest that the majority of these ships came here by accident. Rather, the context, 
in shallow water inside protected bays, seems to indicate that we are dealing either with discarded vessels, or vessels which were intentionally sunk. It is noteworthy that the situation in Skjernesund, with more than one wreck, is replicated in other major harbours known from written sources - at Langesund, Ny-Hellesund and Selør, in particular.

Then there is the dates of the wrecks. In theory, if the wrecks were the result of accidents at sea, one would expect either a more or less even distribution through time, or perhaps an increase as the volume of seaborne trade expanded. However, this is not the picture from the available dates (Fig. 7). Instead, the dates cluster in the late fourteenth and early fifteenth centuries. Two of the dendro-dated vessels belong in this period (1380 and 1389), and so do as many as eight of the C14 dated vessels. Another four seem to date from the mid-fifteenth century and yet another four from around 1500. There are only few dated wrecks earlier or later than this. This chronological distribution could indicate that we, to a certain degree, are dealing with particular historical events, and not processes related to 'natural' losses at sea. At least in a couple of cases this idea finds considerable support in the find context. The two wrecks near Langesund (Fig. 6, nos 2 and 3) both show traces of burning, and the C14 dates indicate that they are contemporary (1287-1385 and 1300-1400, respectively). The distance between these two wrecks is only c. $700 \mathrm{~m}$. In Ny-Hellesund, further west, one dated wreck (Fig. 6, no. 18) was loaded with limestone tiles from the Baltic. At another position in the harbour is a further load of similar tiles, probably indicating another wreck, and there are some indications that there might have been a third wreck nearby. Again, it is tempting to suggest that what we are observing are the remains of historical events, and not just ships that accidentally ended in these harbours. Contemporary written sources give us more than a clue as to what these events were. Again, the key word is piracy.

\section{Piracy in Skjernesund and other places - the documentary evidence}

The documentary evidence for the activities in the waters of southern Norway are primarily drawn from either Hanseatic, English or Norwegian (later Danish) sources, while the contemporary Norse sagas have some evidence for the early period. The latter mostly focus on operations and movements by the opposing factions during Norway's civil wars 1130-1240, and a number

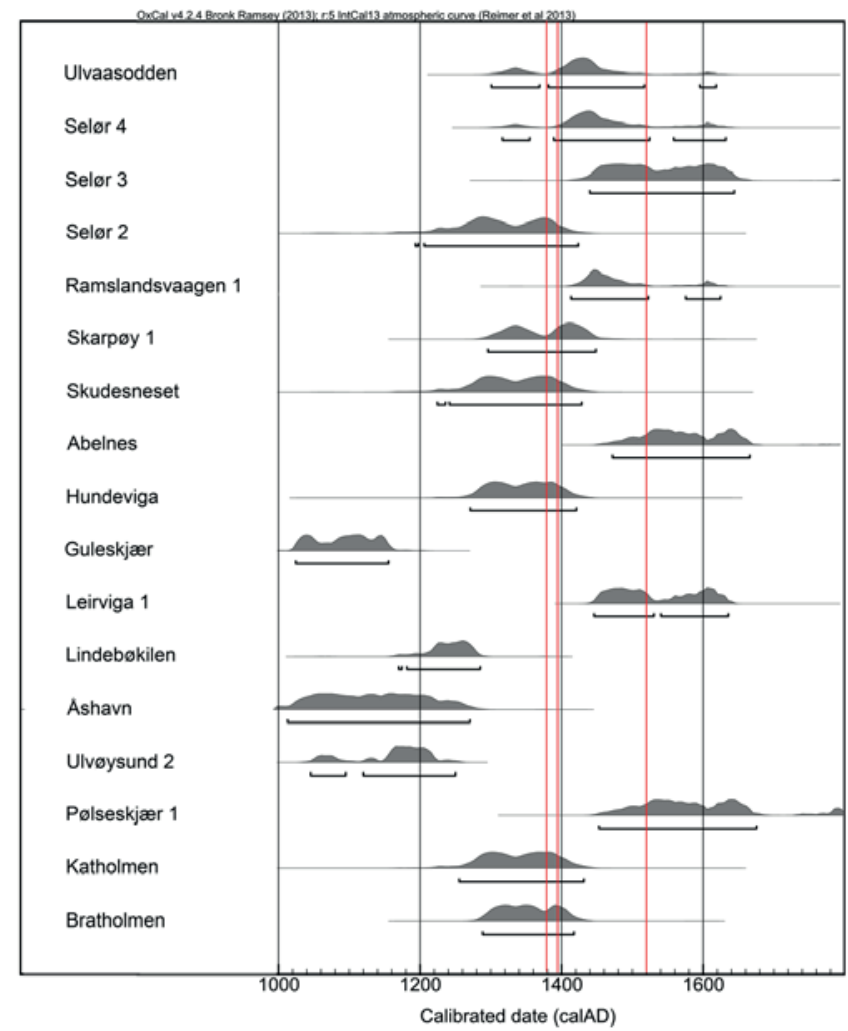

Fig. 7. Overview of C14 dates of 17 shipwrecks from the counties of Telemark to Vest Agder (illustration: Pål Nymoen, Norwegian Maritime Museum and FransArne Stylegar).

of Norwegian harbours known from later times are mentioned, some of them a few times, such as Portør $\left(1137,{ }^{26} 1206,{ }^{27} 1207,{ }^{28} 1227^{29}\right)$ and Selør $\left(1156,{ }^{30} 1190,{ }^{31}\right.$ $1207^{32}, 1224,{ }^{33} 1227^{34}$ ). Langesund (Slåttenes) is mentioned for the first time in 1240, and so is Skjernesund, where King Haakon Haakonsson's fleet took refuge to repair their damaged ships after a severe storm. ${ }^{35}$

Apart from the references in the sagas, which mainly relate to the first decades of the thirteenth century, the documentary sources when they mention harbours and outports from the rest of our period are almost exclusively concerned with skirmishes and piracy. Two of these sources dated to the early years of the fourteenth century deal with English complaints against Norway. In 1307 the earl of Gloucester's merchant, Tidemann de Lippa, complained to the king of England that on his way from Boston to Russia with a ship from Rostock laden with clothes and other goods, he was attacked in Hesnes harbour by officers in the service of the Norwegian king, who confiscated the cargo. ${ }^{36}$ Nine years later, King Edward wrote to King Haakon V on behalf of John de Bedford, burgher in Kingston on Hull, and whose ship, Godyer, on its way to Newcastle, had been driven to Selør, where the knight, Snare 
Aslaksson drove away skipper and crew and confiscated both ship and cargo. ${ }^{37}$

Interestingly, the next and by far the most intensive phase of piracy began in 1397, and the Hanse played an important part. That year, William Squier from Hull's ship was taken by men from Friesland; later on, the Frisians paid damage in the form of a captured ship from Zeeland laden with planks of pine. In Langesund harbour on their way home to England, Squier and his crew took onboard some men from Zeeland, who claimed that the ship belonged to them. ${ }^{38}$ The year after in Langesund, the pirates Gödeke Michels and Klaus Störtebeker with confederates of the Hanse took a crayer, called the Peter and belonging to Thomas Motte of Cley. ${ }^{39}$ In 1399, the English complained at the congress in the Hague that men from Hamburg had taken oil and other goods belonging to Lynn merchants in Egersund. ${ }^{40}$ Then, in 1401, the English complained at the congress in the Hague that two men from Lübeck, masters of a ship from Bergen equipped for war, had taken goods from a ship from Zierikzee in Ny-Hellesund, carrying merchandise belonging to a Lynn merchant. ${ }^{41}$ That same year men from Wismar and Rostock took a ship from West-Stow in Zeeland, which belonged to John Hughson of Yarmouth and which was laden with hides of oxen and sheep, butter, timber, whetstones etc., in Langesund. ${ }^{42}$ Over the next few years, there were similar incidents on an almost regular basis. Consequently, in 1403, the city council of Stralsund complained that the English took a ship belonging to a man from Stralsund at Selør. ${ }^{43}$ In 1405, the crew of a Danzig ship took goods belonging to merchants in Lynn in Selør harbour ${ }^{44}$ and men from Wismar took a ship from Yarmouth, belonging to William Oxney, and laden with salt, cloth, and salmon, also in Selør harbour. ${ }^{45}$ In 1406, thirteen Hanse ships were captured by Frisians in Skjernesund. ${ }^{46}$ That same year, a hundred fishermen from Cromer and Blakeney were killed by Germans from Bergen in Wynforde, that is Kvinesfjord in Vest-Agder. ${ }^{47}$ In 1407, Hamburg complained at the congress in the Hague that Englishmen from Lynn, Scarborough, and Blakeney had captured a ship of theirs in Hesnes harbour. ${ }^{48}$ Then, two years later, the skipper Johan Rudemann on his way to Sluis in Flanders with cargo belonging to Hanse merchants, had lain in Skjernesund with his hulk together with several other ships, when pirates from Friesland seized both ship and cargo and took it to France. ${ }^{49}$ Perhaps the latter episode during this rather intensive phase occurred in 1412, when Klaus Belckow from Danzig's ship, laden with beer, flour and malt and destined for
Bergen, was captured by Scots by Cape Lindesnes, and Klaus and three others were left behind in a boat, while the remaining sailors were taken to Aberdeen. ${ }^{50}$

In the following years, there were a few more incidents, but it seems that they did not occur as often as in the preceding period. In 1418, a ship from Newcastle and its cargo was seized in Skjernesund by men in the service of the duke of Schleswig, ${ }^{51}$ with two more episodes to follow in 1424 and 1427, in Lista and Skjernesund respectively. In the latter, Peter Michels from Wismar took from two Prussian merchants butter, pelts, and silver. ${ }^{52}$ The next mention is in 1454, when Hanseatic merchants complain to King Christian I that Norwegians, Olav Nilsson, the king's governor in Bergen, and Nyelsz Peterssen had taken several laden ships in Skjernesund, while Clawes Ghysen had taken eleven ships in Selør. ${ }^{53}$ A few years before, in 1450, King Christian I had stayed in Skjernesund on his way from Trondheim, where he had been crowned king of Norway, to Denmark. ${ }^{54}$

In 1484, two new episodes occurred, when Jurgen Henke's ship was wrecked near Lista, laden with herring, and he and his crew were attacked by the king's subjects, who took most of the cargo and fishing equipment, ${ }^{55}$ and men in the service of Junker Jakobs of Oldenburg took a hulk belonging to Thewes Smyt from Wismar, laden with flour, beer etc. at Ny-Hellesund. ${ }^{56}$

Another 'phase' of piracy began in 1511, when Danzig burghers complained that three of their ships were taken by Auslieger (guard ships) from Lübeck at Flekkerøy on their way back to Danzig. ${ }^{57}$ The year after the Scots took three ships belonging to Mathies Kegebeyu and Werkentyn, and en route to Bergen, in Skjernesund, ${ }^{58}$ while in 1516 Jens Olefszen in Varberg and other burghers complained that their ships and cargoes were captured in the harbours of Selør and Merdø by Cordt Konningk and Clauwes Toden. ${ }^{59}$

Then there are the events in the 1520 s, when the deposed king, Christian II tried to regain the throne through privateering on the coast of southern Norway. In 1525, the royal governor Vincents Lunge wrote to archbishop Olav that the caravel Peter van Höll, which traitors had stolen from the king, lay in Skjernesund, ${ }^{60}$ and the year after, as already mentioned, Hans Michelsson informed King Christian II that skipper Clement lay with five ships in Skjernesund, where he had erected two blockhouses and closed the harbour with iron chains. ${ }^{61}$ In 1527, Vincents Lunge wrote to archbishop Olav about skirmishes with King Christian II's privateers in Hesnes and Egersund. ${ }^{62}$ Again, in 1531 King Christian declared to the people of Norway that 
he had come to Hesnes harbour with a large number of men with the intention of freeing the country from the usurpers, ${ }^{63}$ and the same year he wrote a letter to the Danish nobility from Skjernesund. ${ }^{64}$

It is obvious that the time around 1400 stands out, and it is hard to avoid the conclusion that the cluster of shipwrecks dated to this period is related to similar events as those mentioned in the cited documents. This idea is strengthened by the fact that a number of the dated wrecks are indeed situated in the very same harbours mentioned in the contemporary written sources (Langesund, Ny-Hellesund, Skjernesund, Selør). Indeed, in some cases we may actually be able to infer what specific events led to the ships' demise. There is an argument, for instance, that the dendrodated Wreck 3 in Skjernesund is directly related to the event in 1406. The wrecked ship was built in 1389 in northern Poland. ${ }^{65}$ The incident seventeen years later involved thirteen ships from the Wendish towns Elbing, Danzig and Reval. It is also necessary to mention the dendro-dated wreck from Flekkerøy (Fig. 6, no. 11), which was also built in northern Poland, in 1508 or shortly thereafter. This could be one of the three Danzig ships which were taken by Auslieger from Lübeck at Flekkerøy in 1511.

\section{The political background}

The years around 1400 were, without doubt, a special period at sea. C. J. Ford wrote that 'the opening years of the fifteenth century witnessed an outburst of lawlessness at sea of such intensity that legitimate commerce between the kingdom of France and England, and their allies, all but ceased' ${ }^{66}$ Things were no better at the opposite end of the great northern European trade route. In the Baltic, the Hanse and other merchants faced danger from raids of the so-called Vitalienbrüder (Victual Brothers) and other less defined groups of pirates and privateers, originally hired by Albrecht of Mecklenburg, king of Sweden, in 1392 against Margrete, queen of Denmark and Norway. ${ }^{67}$ The Vitalienbrüder were 'the most notorious seaborne thieves in Hanseatic history. ${ }^{68}$ The troubles in Scandinavia had begun in 1375, when King Valdemar of Denmark's death had caused a crisis of succession into which the Hanse were quickly drawn. The Hanse was also locked in a seemingly never-ending cycle of reprisals and counterreprisals with the English, starting in 1385, when an English squadron unprovoked attacked and seized a Hanse fleet in the Zwijn. ${ }^{69}$ The English furthermore had unfinished business with their Scottish neighbours to the north, and the most intensive phase of naval hostilities between the Hanse and England began in 1401, when the Grand Master of the Teutonic Order refused to oblige when King Henry told him to stop trading with the Scots. ${ }^{70}$

The English involved in the Baltic trade had complained in 1398 that the Hanse towns had interfered in their business and treated them badly. King Henry IV answered by reminding the Hanse that their privileges in London had been granted on the premise that English merchants should have the same freedoms in Germany, and that the privileges would be withdrawn if the illegal actions continued. During the Hanseatic Diets (Hansetage) in 1405 and 1407, the English demanded reparations for cases of piracy. Even so, the conflict continued, the Hanse captured English ships and the English captured German ones, sometimes with whole crews murdered in the process. The Hanse, furthermore, were accused of ruining ships belonging to merchants from York, Hull, Yarmouth, Lynn and other English towns. Then, in 1411, King Henry arrested a number of Hansards in Boston while declaring that he would keep them prisoners until reparations had been paid for the injuries, damages and murders suffered by English merchants in Norwegian harbours. ${ }^{71}$

In the ongoing conflict, the English side was preoccupied by one incident in particular, namely the murder of a hundred fishermen from Norfolk in the harbour of Wynforde in the summer of 1406. The events were related in a letter of complaint from King Henry IV to Erik of Pomerania, king of Denmark and Norway, which stated that fishermen from Cromer and Blakeney had escaped 'the cruelty and rudeness of the Flemings' by seeking refuge in the harbour (Wynforde), that is, Kvinesfjorden, today more commonly called Fedafjorden, where they were attacked by a fivehundred-man strong force of 'certain merchants from the German Hanseatic towns, who usually frequented Bergen' and who hid themselves at Hidra (Itro). As soon as the fishermen reached land, a couple of them were killed by the Germans 'in the cruellest way', while the rest were put in prison and a few days later thrown into the sea where they drowned..$^{72}$ The king's letter was followed up in early 1407 by a complaint to King Henry from 85 named women and men in Cromer, stating that their husbands, sons, brothers, brothers-in-law and servants had been murdered by Hanse merchants from Bergen in Kvinesfjord the previous summer. ${ }^{73}$ Later that year, King Henry declared that the Hanse merchants had been cleared of the charges, and that a settlement had been reached with the complainants. 
But the murders in Wynforde did not disappear from the diplomatic order of the day. In 1412 King Henry declared that he had received a letter of complaint from the Bergen traders in King's Lynn, regarding the behaviour of the Hansards in Bergen and various crimes committed by them in other places in Norway, among them the massacre in Kvinesfjord a few years before. ${ }^{74}$

The Flemish towns were faced with crisis at the time. The deterioration of relations and the ensuing unofficial 'sea war' between England and France after the coup d'etat in England in 1399 had severe consequences for Anglo-Flemish trade, and for the supplies of wool to the burgeoning textile industry in Flanders. At the beginning, the ruling dukes of Burgundy tried to pursue pro-French policies and most of the coastal Flemish towns - Nieuport, Sluis, Dunkirk and Gravelines, in particular - were involved in the flourishing piracy in the English Channel. In 1404, when deputies from Bruges, Ghent and other major Flemish towns went to Nieuport to estimate the damage caused by pirates equipped from that town to merchants from Brabant and of the Hanse, they found that in one day as many as seven ships had been captured near the coast of Nieuport. Merchant, as well as fishing vessels were seized, both by English and Flemish pirates. ${ }^{75}$

The other major episode on the Agder coast in 1406 was of course the capture of thirteen ships in Skjernesund. The culprits here were, according to contemporary sources, 'Frisians'. But were they actually Frisians? It is in fact more likely that they were the infamous Victual Brothers. The term had its origins in the Baltic in the 1390s, even if vitaillers was used as a term for pirate ships bringing supplies during the siege of Calais in 1347, in one of the seemingly endless conflicts between the English and the French in the late medieval period. ${ }^{76}$ It was said about the Victual Brothers that 'se weren Godes vrende unde al der werlt vyande' (they were God's friends and all the world's foes). ${ }^{77}$ Their alternate name in contemporary sources, Likedeeler (equal sharers), indicates that a kind of democratic spirit prevailed among them. ${ }^{78}$

The Victual Brothers represented a considerable political factor in the early fifteenth century. Most of their early leaders had their origins in the lower aristocracy in Mecklenburg, whose royal house was involved in the ongoing fight for the Swedish crown, and thus invited all freebooters in the Baltic, 'alle, die das Reich Dänemark schädigen wollen' (all those who wanted to inflict pain on the Kingdom of Denmark), to operate freely from the ports of Mecklenburg - Wismar and Rostock. ${ }^{79}$ Subsequently, the Victual Brothers were involved in most of the power struggles in the Baltic between the Hanse towns, the Teutonic Order and various duchies, and in the fights for royal power in Sweden, Denmark and Norway. Their attack on Bergen in 1393 had dire consequences for trade between England and Norway. ${ }^{80}$ Another attack on Bergen, in 1428, may also be related to the Victual Brothers and their successors. ${ }^{81}$ Various sources show that these pirates also frequented the ports of southernmost Norway on many occasions. Their leader, Klaus Störtebeker himself took an English crayer in Langesund in 1398. Two of their other leaders, Magister Wigbolt and Gödeke Michels, escaped to Norway and stayed there for a whole winter with more than two hundred of their company, probably in the winter of $1399-1400,{ }^{82}$ while Störtebeker and others fled to Holland. Around 1400, most of the Victual Brothers stayed with Häuptlinge (chieftains) in Frisia, and for years to come, they became associated with 'Frisians'. ${ }^{83}$ It was to these Frisian chieftains that the Hansards sent envoys after the event in 1406, to ask the whereabouts of their ships and their cargo ${ }^{84}$ Klaus Störtebeker was captured and hanged off Heligoland in October 1400 through the combined efforts of Lübeck, Hamburg, Bremen, Rostock, Wismar and Stralsund, and the Prussian and Dutch towns, with the backing of Queen Margrete, while Wigbolt and Michels were taken in March or April 1401, brought to Hamburg and beheaded at the Grasbrook. ${ }^{85}$

One other piece of archaeological evidence can indeed, should - be seen through the lens of piracy, specifically Victual Brother piracy. This is the outstanding coin treasure from the inlet Todeviga in Spangereid, near Lindesnes and midway between Skjernesund and Selør. The treasure consists of 243 silver coins, almost exclusively witten from Hanse towns, with a terminus post quem of 1392. It is almost certain that these coins never circulated in Norway, and they seem to have been kept in some form of coin rolls when hidden in the ground. This was most likely a hidden treasure in the true, popular meaning of the term. ${ }^{86}$

One of the coins in the find may indicate a more direct connection with the Victual Brothers. It is a witten, minted for the Frisian chieftain Edo Wiemken (1358-1410). It is a rare coin, and the only one of its kind in Norway. Edo Wiemken was a major local ally of the pirates, who in 1398 had assured the Hanse towns that he would no longer have anything to do with 'diese Vitalienbüder oder andere Vitalienbrüder oder andere Leute, die den Hansestäden oder ihren Kaufleuten Schaden beigebrach haben...' (these Victual Brothers or other Victual Brothers or other people who do damage 
to the Hanse cities or their merchants). ${ }^{87}$ Although Edo was by no means the only prominent pirate from a Frisian harbour, it is interesting to note that it was he who argued forcefully against the execution of Michels and Wigbolt three years later, and even demanded that they should be released into his custody. ${ }^{88}$

A coin hoard from Loshavn harbour in Lista is also of considerable interest. With a terminus post quem of 1390, it consists of twenty-six Scottish groats and halfgroats. ${ }^{89}$ Both the find context, in a relatively isolated outport, and the fact that single finds of Scottish coins do not occur in Norway after 1387, suggest that these coins, too, were hidden by seafarers.

\section{Concluding remarks}

The dangers lurking in the waters of southern Norway are underscored by the text accompanying a painting in the Marienkirche in Lübeck. 'Let those about to embark go to confession. It took so little time for us to lose our lives', it says, under a painting depicting the shipwreck of a Bergenfahrer..$^{90}$ Two of the ships' masts are broken; several seamen are in the water, some of them clinging to planks or other objects, others swimming. A couple of the men appear to be praying, having reached the shore. This shipwreck happened in 1489, as indicated by another inscription: 'In $1489 . .$. skipper Hans Ben was shipwrecked in Berksunde with 33 men...Pray for their souls!' ${ }^{11}$ Berksunde is present-day Berefjord in Vest-Agder, near the county border with Rogaland. But as we have shown in the preceding pages, shipwreck was not the only danger confronting Hanse sailors.

Dated wrecks and some other archaeological sources point to the coast of Agder as important to the Hanse around 1400, but also to pirates, primarily the Vitalienbrüder. In this paper, our focus has been the harbour of Skjernesund, but similar stories could probably be told about other ports and outports in southern Norway, too, as indicated both by contemporary documentary sources and archaeology - places such as Egersund, Selør, Ny-Hellesund and Langesund, as well as Marstrand in present day Sweden, which were frequented by both pirates and Hanse merchants in our period.

Although letters of marque had been in use since the thirteenth century, it is anachronistic to speak of privateers during this early period. ${ }^{92}$ But the fact is that many of the events that both contemporary sources and modern historians have described as regular piracy, were in fact integrated parts of official policy, whether French, English or Hanseatic. ${ }^{93}$ The same goes for the
Vitalienbrüder, who were behind some of the attacks against Hanse ships in the harbours mentioned above.

The question remains whether there is a direct connection between the wrecks discussed in this article, such as the ones in Skjernesund, and specific events related in contemporary documents. We believe it to be likely in some cases, and we would argue at least that in the period when most of the late medieval wrecks on the coast of southern Norway date from - the time around 1400 - there could be very good reasons for the disappearance of merchant ships. Piracy was never as intensive along the great northern European trading route as it was in these years. It should come as no surprise that the Skagerrak coast of Norway together with the Bohuslän coast in present-day Sweden had to bear some of the burden in this respect.

Skjernesund, in particular, shows signs of having been a regular pirates' nest at times; not only in the 1520s, when King Christian's privateers commandeered the Agder coast with Skjernesund as their home port, but also in the early fifteenth century. However, while the pirates in 1526 made Skjernesund into a safe refuge by erecting two blockhouses and closing the entrance to the harbour using iron chains running across the sound, we have only the shipwrecks, as supposed victims of the pirates, and the documentary sources to tell the story about the pirates in the earlier period. And unlike the early sixteenth century and the period that followed ${ }^{94}$ we still know little about what traces a pirates' port from around 1400 would leave. Hopefully, future research in Skjernesund and other ports and outports discussed in the preceding pages will improve this situation.

\section{Endnotes}

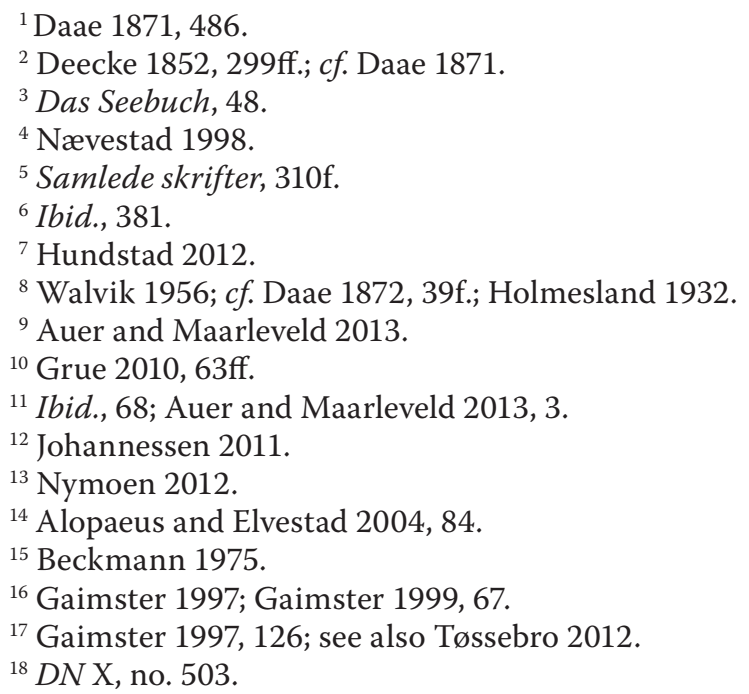


${ }^{19}$ Krause 1887.

${ }^{20}$ Teisen 1994, 75.

${ }^{21}$ 'Nun lag eine große Hulke in einer Wiek zwischen dem Bauerhofe und unsern Espingen; die hatten die Seeräuber genommen und aufgehauen; wenn niedrig Wasser war, lag sie trocken; war's aber hoch, so stand sie voll Wasser.' Quoted from Deecke 1852, 303.

${ }^{22}$ Ibid.

23 'Die Schute, die vor ihm läuft, wird Feuer an uns bringen.' Quoted from Deecke 1852, 305f.

24 'Wir aber nahmen die Güter und das Beste vom Tau und Takel, Ankern und Segeln, und verbrannten das Schiff dann.' Quoted from Deecke 1852, 310.

${ }^{25}$ See Nævestad 1998 for a, now somewhat outdated, overview.

${ }^{26}$ Inga saga ok bræðra hans, ch. 8.

${ }^{27}$ Böglunga sögur, ch. 7.

${ }^{28}$ Inga saga ok brceðra hans, ch. 18.

${ }^{29}$ Hákonar saga Hákonarsonar, ch. 147.

${ }^{30}$ Inga saga ok brcera hans, ch. 30.

${ }^{31}$ Profectio Danorum in Hierosolymam, ch. 10.

${ }^{32}$ Inga saga ok brceðra hans, ch. 18.

${ }^{33}$ Hákonar saga Hákonarsonar, ch. 106.

${ }^{34}$ Ibid., ch. 157.

${ }^{35}$ Ibid., ch. 227.

${ }^{36}$ DN XIX, no. 456.

${ }^{37}$ Ibid., no. 496.

${ }^{38}$ Ibid., no. 632.

${ }^{39}$ Ibid., no. 666 .

${ }^{40}$ Ibid., no. 716 .

${ }^{41}$ Ibid., no. 714.

${ }^{42}$ Ibid., no. 666

${ }^{43}$ Ibid., no. 664.

${ }^{44}$ Ibid., no. 718.

${ }^{45}$ Ibid., no. 666 .

${ }^{46}$ HR I, 5, nos 346, 347.

${ }^{47}$ Ibid., 6, no. 78, \$ 3; cf. Stylegar 2014.

${ }^{48}$ DN XIX, no. 715.

${ }^{49}$ HUB 5, nos 963, 982.

${ }^{50}$ HR I, 6, no. 76.

${ }^{51}$ HUB 6, no. 154

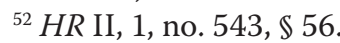

${ }^{53}$ Ibid., 4, no. 349, $\$ 5$, 13; cf. DN XVI, no. 291.

${ }^{54}$ DN IV, no. 924

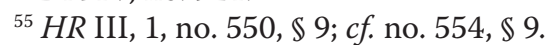

${ }^{56}$ Ibid., 1, no. 560.

${ }^{57}$ Ibid., 6, no. 251; cf. HR III, 7, no. 43, $\$ 4-6$.

${ }^{58}$ Ibid., 6, no. 488, $\$$ 6; cf. no. 581, $\$ 10$, nos 492, 496.

${ }^{59}$ Ibid., 6, no. 725, $\$ 33$.

${ }^{60}$ DN VII, no. 614.

${ }^{61}$ DN X, no. 503.

${ }^{62}$ DN VIII, no. 558.

${ }^{63}$ Ibid., no. 653.

${ }^{64}$ Ibid., no. 650.

${ }^{65}$ Daly 2011.

${ }^{66}$ Ford 1979, 63.

${ }^{67}$ Puhle 2012.

${ }^{68}$ Pitcaithly 2011, 137.

${ }^{69}$ Ibid., 14.

${ }^{70}$ Lloyd 2002, 112.

${ }^{71}$ HUB 5, nos 1023-5.

${ }^{72} \mathrm{DD}$, no. 14060723002 .

${ }^{73}$ DN XIX, no. 707.
${ }^{74}$ Ibid., no. 729.

${ }^{75}$ Mayzlish 2010.

${ }^{76}$ Bracker 2005, 61.

${ }^{77}$ Ibid., $60 \mathrm{ff}$.

${ }^{78}$ Puhle 2005, 40f.; Bracker 2005, $81 \mathrm{ff}$.

${ }^{79}$ Puhle 2012, 36ff.

${ }^{80}$ Bugge 1933, 267ff.; Helle 1982, $781 \mathrm{f}$.

${ }^{81}$ Imsen and Sandnes 1987, 349f.; see also Geir Atle Ersland, this volume.

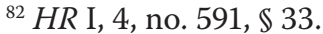

${ }^{83}$ Puhle 2005, 103ff.; Schmidt 2005.

${ }^{84}$ HR I, 5, no. 346.

${ }^{85}$ Rohman 2007; Pitcaithly 2011, 23.

${ }^{86}$ Hellan 2012, 67; cf. Holst 1938.

${ }^{87}$ Ostfriesisches Urkundenbuch, quoted after Puhle 2012, 111.

${ }^{88}$ HR I, 5, no. 44; cf. Bracker 2005, 67.

${ }^{89}$ Hellan 2012, 85.

${ }^{90}$ Dollinger 1970, 182.

${ }^{91}$ Die Lübecker Bergenfahrer und ihre Chronistik, 5.

${ }_{92}$ Pitcaithly 2011, 70.

${ }^{93}$ Ford 1979.

${ }^{94}$ See for instance Kelleher 2013.

\section{References}

Printed sources (see also list of abbreviations)

Böglunga sögur, in S. Jakobsson et al. (eds), Hákonar saga Hákonarsonar, Boglunga saga, Magnúss saga lagabœtis. Íslenzk fornrit, 31-32. Reykjavík: Hið íslenska forn ritafélag, 2013.

Hákonar saga Hákonarsonar, in S. Jakobsson et al. (eds), Hákonar saga Hákonarsonar, Boglunga saga, Magnúss saga lagabœtis. Íslenzk fornrit, 31-32. Reykjavík: Hið íslenska fornritafélag, 2013.

Inga saga ok breðra hans, in A. Finlay and A. Faulkes (trans.), Heimskringla, vol. 3: Magnús Óláfsson to Magnús Erlingsson. London: University College London.

Die Lübecker Bergenfahrer und ihre Chronistik, by F. Bruns. Berlin: Pass und Garleb, 1900.

Profectio Danorum in Hierosolymam, in A. Salvesen (trans.), Norges historie. Historien om de gamle norske kongene av Theodricus tr. Historien om danenes ferd til Jerusalem. Thorleif Dahls kulturbibliotek. Oslo: Aschehoug, 1969.

Das Seebuch, ed. A Sauer. Hamburg: Kabel, 1997.

Samlede skrifter, P. Claussøn Friis. Kristiania: A. W. Brøgger, 1881.

\section{Secondary literature}

Alopaeus, H., and Elvestad, E. 2004. Avaldsnesskipet - et 'nordisk' skip fra Polen? Stavanger Sjøfartsmuseums årbok, 73-86.

Auer, J., and Maarleveld, T. (eds) 2013. Skjernøysund Wreck 3, fieldwork Report 2011. Maritime Archaeology Programme, Archaeology Reports 5. Esbjerg: University of Southern Denmark.

Beckmann, B. 1975. Der Scherbenhügel in der Siegburger Aulgasse, vol. 1. Bonn: Rheinland Verlag.

Bracker, J. 2005. Klaus Störtebeker - nur einer von ihnen. Geschichte der Vitalienbrüder, in W. Ehbrecht (ed.), 
Störtebeker - 600 Jahre nach seinem Tod, 57-84. Trier: Porta Alba Verlag.

Bugge, A. 1933. Den Norske Sjøfarts Historie 1. Skibsfarten fra de oldste tider til omkring aar 1600. Kristiania: Steenske forlag.

Daly, A. 2011. Dendrochronological Analysis of Oak from a Shipwreck, Skjernøysund 3, Mandal, Norway. Online report, University College Dublin: http:// researchrepository.ucd.ie/handle/10197/3559

Daae, L. 1871. Martin Pechlin, en sørøverhistorie fra det sextende Aarhundre. Historisk Tidsskrift 1, 485-497.

Daae, L. 1872. Norske Bygdesagn, vol. 2. Christiania: Cappelen.

Deecke, E. 1852. Lübische Geschichten und Sagen. Lübeck: Boldemann.

Dollinger, P. 1970. The German Hansa. Princeton: Stanford University Press.

Ford, C. J. 1979. Piracy or policy: the crisis in the Channel, 1400-1403. Transactions of the Royal Historical Society $29,63-78$.

Gaimster, D. 1997. German Stoneware 1200-1900. London: British Museum Press.

Gaimster, D. 1999. The Baltic ceramic market c. 12001600: An archaeology of the Hanse. Fennoscandia archaeologica 16, 59-69.

Grue, M.-L. P. 2010. Dutch influence on early Scandinavian carvel-constructed ships. Unpublished MPhil thesis, University of Southern Denmark.

Hellan, T. 2012. Utenlandsk mynt $i$ Norge ca. 1350-1483. Unpublished Master thesis, Trondheim University.

Helle, K. 1982. Bergen bys historie I. Bergen: Universitetsforlaget.

Holmesland, P. 1932. Bataljen i Sundene. Bidrag til Agders historie 14, 28-35.

Holst, H. 1938. Numismatiske minner fra Hansaveldet i Norge. Norsk Numismatisk Årsskrift, 89-108.

Hundstad, D. 2012. Outport communities in the south of Norway - maritime monocultures, in R. Gorski and B. Söderqvist (eds), The Parallel Worlds of the Seafarer: Ashore, afloat and abroad, 29-48. Gothenburg: Maritime Museum \& Aquarium Association of North Sea Cities.

Imsen, S., and Sandnes, J. 1987. Norges historie 4. Oslo: Cappelen.

Johannesen, J. 2011. Rapport kulturmiljø Skjernøysund. Oslo: Norsk Maritimt Museum.

Kelleher, C. 2013. Pirate ports and harbours of west Cork in the early seventeenth century. Journal of Maritime Archaeology 8, 347-366.

Krause, K. E. H. 1887. Marten Pechlin, in Allgemeine Deutsche Biographie vol. 25, 308-309, ed. Historische
Kommission der Bayerischen Akademie der Wissenschaften. Leipzig: Dunker \& Humblot.

Lloyd, T. H. 2002. England and the German Hanse, 1157-1611. A Study of their Trade and Commercial Diplomacy. Cambridge: Cambridge University Press.

Mayzlish, A. 2010. Flemish Towns: Maritime Trade and Fighting with Piracy in the Beginning of the XVth century. Unpublished conference paper, European Association for Urban History, Ghent, 2010.

Nymoen, P. 2012. Hansaspor. Norsk Maritimt Museum årbok, 195-211.

Nævestad, D. 1998. Lokaliserte middelaldervrak i ØstNorge. Norsk Sjøfartsmuseum årbok, 159-207.

Pitcaithly, W. M. E. 2011. Pirates, Robbers and Other Malefactors. The role played by violence at sea in relations between England and the Hanse towns 13851420. Unpublished PhD thesis, University of Exeter.

Puhle, M. 2005. Die Vitalienbrüder - Söldner, Seeräuber? in W. Ehbrecht (ed.), Störtebeker - 600 Jahre nach seinem Tod, 15-21. Trier: Porta Alba Verlag.

Puhle, M. 2012. Die Vitalienbrüder. Klaus Störtebeker und die Seeräuber der Hansezeit. Frankfurt: Campus Verlag.

Rohman, G. 2007. Der Kaperfahrer Johann Stortebeker aus Danzig. Beobachtungen zur Geschichte der 'Vitalienbrüder'. Hansische Geschichtsblätter 125, 77-119.

Schmidt, H. 2005. Das östliche Friesland um 1400. Territorialpolitische Strukturen und Bewegungen, in W. Ehbrecht (ed.), Störtebeker - 600 Jahre nach seinem Tod, 85-109. Trier: Porta Alba Verlag.

Stylegar, F.-A. H. 2014. Tragedien ved Hidra 23. juli 1406, in J. H. Trelsgård (ed.), Bygdebok for Hidra herred. Gård og slekt, vol. 1, 23-25. Flekkefjord: Flekkefjord historielag.

Teisen, M. 1994. A medieval clinker built wreck at Hundevika, Norway, in C. Westerdahl (ed.), Crossroads in Ancient Shipbuilding: proceedings of the Sixth International Symposium on Boat and Ship Archaeology, Roskilde, 1991, ISBSA 6, 74-76. Oxford: Oxbow Books.

Tøssebro, C. 2012. Wine and power. A spatial and stratigraphical study of the pottery and glass assemblages from the wine cellar in Bergen, Norway. Historische Archäologie 2012. Published online http:// www.histarch.uni-kiel.de/HistArch_2012_high.pdf [last access december 2017].

Wahlöö, C. 1976. Keramik 1000-1600 i svenska fynd. Archaeologica Lundensia VI. Lund: Lunds universitet.

Walvik, E. P. 1956. Skjernøya: Gamle minner og slekter. Mandal: Salvesen. 